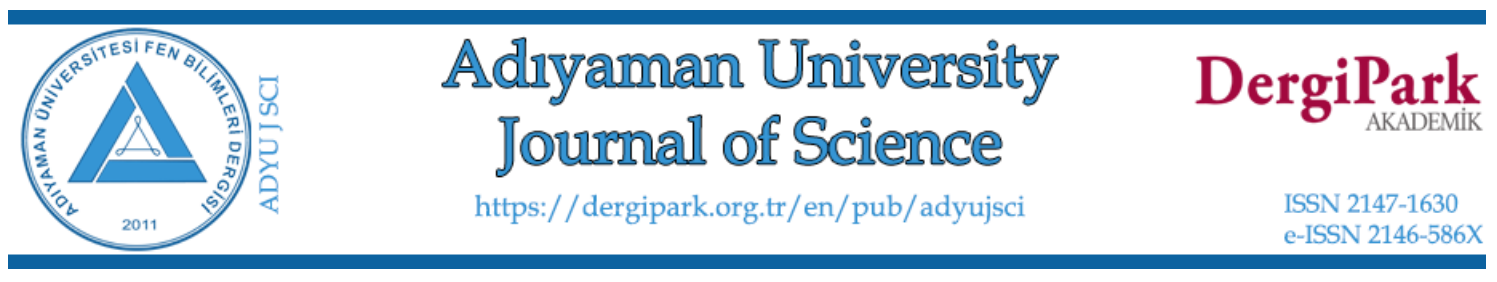

\title{
In-depth Profiling of $N$-glycans Isolated from Ostrich Egg White and Yolk Glycoproteomes by HPLC-HILIC-FLD-MS/MS
}

\author{
Hacı Mehmet KAYILI ${ }^{1, *}$ \\ ${ }^{I}$ Karabük University, Department of Biomedical Engineering, Karabük, Turkey \\ h.mehmetkayili@karabuk.edu.tr,ORCID:0000-0002-6740-0645
}

\begin{abstract}
Protein glycosylation is an essential post-translational modification and modulates critical cellular events. It is known that $\mathrm{N}$-glycosylated proteins from egg white and yolk are played crucial roles in various cellular pathways. Characterization of $\mathrm{N}$-glycan structures of glycoproteomes is required to understand these functions. Therefore, this study is aimed to characterize the $\mathrm{N}$-glycan profiles of ostrich egg white and yolk glycoproteomes. In the study, $\mathrm{N}$ glycans were released from ostrich egg white and yolk glycoproteomes by an enzymatical process and labeled with a procainamide tag. Samples were analyzed by HPLC-HILIC-FLD-MS/MS (high-performance hydrophilic interaction liquid chromatography with fluorescence and tandem mass spectrometric detection). The number of detected $N$-glycans obtained from ostrich egg white and yolk glycoproteomes was found to be 39 and 36, respectively. It was determined that $\mathrm{N}$ glycans of ostrich egg white glycoproteome were highly galactosylated (96.64\%). In addition, bisecting $N$-glycans were abundant in ostrich egg white glycoproteome (91.72\%) compared to ostrich egg yolk glycoproteome (6.74\%). The abundance of high-mannose $\mathrm{N}$-glycans was dramatically higher in the ostrich egg yolk glycoproteome (55.84\%) than the ostrich egg yolk glycoproteome (2.67\%). The fucosylation ratio of $N$-glycans belonging to ostrich egg white and yolk glycoproteomes was detected to be $4.52 \%$ and $0.95 \%$, respectively. The obtained data
\end{abstract}


showed that $N$-glycan profiles of ostrich egg white and yolk glycoproteomes differed significantly.

Keywords: Glycosylation; Glycomics; Ostrich egg white; Ostrich egg yolk; HPLC; Mass spectrometry.

\section{Devekuşu Yumurta Akı ve Sarısı Glikoproteomlarından İzole Edilmiş $N$-glikanların HPLC-HILIC-FLD-MS/MS ile Derinlemesine Profillenmesi}

\section{$\ddot{\mathbf{O} z}$}

Protein glikozilasyonu önemli bir post-translasyonel modifikasyondur ve kritik hücresel olayları kontrol eder. Yumurta akı ve sarısından elde edilen $N$-glikozile proteinlerin çeşitli hücresel yolaklarda önemli roller oynadığı bilinmektedir. $\mathrm{Bu}$ fonksiyonları anlamak için glikoproteomlara ait $N$-glikan yapılarının karakterizasyonu gereklidir. Bu nedenle, bu çalışma devekuşu yumurtası akı ve yumurta sarısı glikoproteomlarının $N$-glikan profillerini karakterize etmeyi amaçlamaktadır. Çalışmada, devekuşu yumurta akı ve sarısı glikoproteomlarından $\mathrm{N}$ glikanlar enzimatik bir süreçle salındı ve bir prokainamid etiketi ile etiketlendi. Örnekler, HPLCHILIC-FLD-MS/MS (yüksek performanslı hidrofilik etkileşim sıvı kromatografisi ile floresans ve ikili kütle spektrometrik dedeksiyon) ile analiz edildi. Devekuşu yumurta akı ve sarısı glikoproteomlarından tespit edilen $N$-glikan sayıları sırasıyla 39 ve 36 olarak bulundu. Devekuşu yumurtası ak1 glikoproteomunun $N$-glikanlarının yüksek oranda galaktozile olduğu $(\% 96,64)$ belirlendi. Ek olarak, bisekte $N$-glikanların devekuşu yumurtası akı glikoproteomunda (\%91.72) devekuşu yumurta sarısı glikoproteomuna (\%6.74) kıyasla bol miktarda bulunmuştur. Devekuşu yumurta sarısı glikoproteomunda yüksek mannozlu $N$-glikanların bolluğu (\%55.84) devekuşu yumurta sarıs1 glikoproteomundan (\%2.67) önemli ölçüde daha yüksek olduğu belirlendi. Devekuşu yumurtası akı ve sarısı glikoproteomlarına ait $N$-glikanların fukozlanma oranı sırasıyla $\% 4.52$ ve \%0.95 olarak tespit edilmiştir. Elde edilen veriler, devekuşu yumurtası akı ve sarısı glikoproteomlarının $N$-glikan profillerinin önemli ölçüde farklılık gösterdiğini göstermiştir.

Anahtar Kelimeler: Glikozilasyon; Glikomik; Devekuşu yumurtası akı; Devekuşu yumurta sarıs1; HPLC; Kütle spektrometresi.

\section{Introduction}

Proteins can be modified covalently after the translation step of the protein synthesis process [1]. These modifications, named post-translational modifications, are prevalent in eukaryote proteomes [2]. Glycosylation is one of the most observed types among posttranslational modifications. Complex oligosaccharides called glycans attach to proteins by several 
enzymatical pathways. By this attachment, the function of the glycosylated proteins is dramatically changed depending on the structures of the glycans [3]. In addition, glycosylated proteins modulate critical biological events in organisms [4]. It is known that glycosylation process changes in various acute diseases [5].

$N$-glycosylated proteins from egg white and yolk are played essential roles in cellular events. For example, it has been reported that ovomicin glycoprotein in egg white has antiadhesive, anticancer, and anti-microbial properties against infectious diseases [6]. Derived glycopeptides from ovumicin bind to E-coli, thereby protecting against E-coli infection [7]. Besides, they provide to determine bacteria in foods [8]. In addition to ovomicin, many other glycoproteins containing ovalbumin, ovotransferrin, ovomucoid, ovoglycoprotein are found in egg white. They have unique biological activities such as antihypertensive, antibacterial, anticancer, etc. It has been suggested that glycans inhibit microorganisms by sticking to intestinal cells [9]. Therefore, in-depth $N$-glycan analysis of egg white and yolk is required to detect potential bioactive elements and determine the functions of these glycoproteins.

Glycomics is a multidisciplinary field focused on characterizing glycan structures to determine their roles in cellular events [10]. Mass spectrometry-based glycomics is the most commonly applied strategy for analyzing glycans derived from different biological samples [11]. Tandem mass spectrometry is allowed to identify $\mathrm{N}$-glycan structures; however, ionization efficiencies of glycans are very low in the mass spectrometric analysis [12-14]. On the other hand, HPLC-HILIC-FLD is a golden standard method for quantitative glycomics. $N$-glycans are labeled with fluorophore tags from their reducing ends in this approach. Recently, a fluorophore tag named procainamide which increases both MS and FLD signals has been introduced to analyze glycans $[15,16]$. When this approach is combined with tandem mass spectrometry, both qualitative and quantitative information is obtained. In addition, some essential $N$-glycan types, including bisecting and core fucosylated glycans, can be detected using tandem mass spectrometry, thereby profiling almost all detected $N$-glycans by this approach $[17,18]$.

Here, a study was undertaken for in-depth profiling of ostrich egg white and yolk $N$-glycans using a glycomics approach. Glycans were first released from glycoproteins extracted from ostrich egg white and yolk proteomes and labeled with procainamide tag. Analysis was achieved using HPLC-HILIC-FLD-MS/MS. Structural analysis of $N$-glycans was performed by tandem mass spectrometry, whereas quantitative data for each detected $N$-glycans were obtained from FLD detection. Thus, $N$-glycans belonging to ostrich egg white and yolk glycoproteins were identified and quantified. 


\section{Materials and Methods}

\subsection{Materials}

Unless otherwise stated, all chemicals used in the study were purchased from Sigma Aldrich (St Louis, MO, USA). Procainamide $\mathrm{HCl}$ was bought from Abcam (Cambridge, UK). PNGase F enzyme was obtained from Promega (Madison, WI, USA). Ostrich eggs were obtained from a local farm in Turkey.

\subsection{Glycan release}

Approximately $2 \mathrm{mg}$ of lyophilized ostrich egg white and yolk were dissolved with $100 \mu \mathrm{L}$ of $2 \% \operatorname{SDS}(\mathrm{w} / \mathrm{v})$ and incubated at $60{ }^{\circ} \mathrm{C}$ for $10 \mathrm{~min}$ by vigorously shaking. Then, $50 \mu \mathrm{L}$ of $4 \%$ Igepal-CA630 (v/v) and $50 \mu \mathrm{L}$ of 5X PBS were inserted to the samples. Finally, $1 \mathrm{U}$ of PNGase

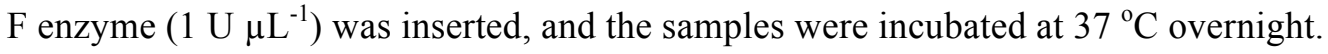

\subsection{Procainamide labeling}

The samples were mixed with $100 \mu \mathrm{L}$ of a labeling solution including $50 \mu \mathrm{L}$ of procainamide hydrochloride (110 $\mathrm{mg} \mathrm{mL}^{-1}$ in DMSO/AA, 7/3, v/v) and $50 \mu \mathrm{L}$ of sodiumcyano bor hydride $\left(60 \mathrm{mg} \mathrm{mL}^{-1}\right.$ in DMSO/AA, 7/3, v/v). Subsequently, the samples were incubated at $65{ }^{\circ} \mathrm{C}$ for $2 \mathrm{~h}$.

\subsection{Purification of procainamide labeling glycans}

The procainamide labeled $N$-glycans were purified using microcrystalline cellulose. First, $200 \mu \mathrm{L}$ of microcrystalline cellulose $\left(0.1 \mathrm{mg} \mathrm{mL}^{-1}\right.$ in $\left.\mathrm{dH}_{2} \mathrm{O}\right)$ was transferred to microtubes and washed with $1 \mathrm{~mL}$ of $\mathrm{dH}_{2} \mathrm{O}$ and $85 \%$ ACN two times, respectively. Then, $150 \mu \mathrm{L}$ of labeled $N$ glycans and $850 \mu \mathrm{L}$ of ACN were inserted into microcrystalline cellulose-containing microtubes. The samples were incubated for $20 \mathrm{~min}$ at room temperature by vigorously shaking. Then, the mixtures were transferred to $1 \mathrm{~mL}$ capacity sep-pack cartridges. To remove impurities and excess dye, microcrystalline cellulose was washed by $1 \mathrm{ml}$ of $85 \%$ ACN including $1 \%$ TFA and $1 \mathrm{~mL}$ of $85 \% \mathrm{ACN}$ three times, respectively. Finally, the elution of the procainamide labeled $N$-glycans were achieved by $750 \mu \mathrm{L}$ of $\mathrm{dH}_{2} \mathrm{O}$. The elutions were then dried using a speed vacuum concentrator. The samples were dissolved with $100 \mu \mathrm{L}$ of $75 \% \mathrm{ACN}$ prior to their analysis with HPLC-HILIC-FLD-MS/MS.

\subsection{HPLC-HILIC-FLD-MS/MS analysis}


HPLC-HILIC-FLD-MS/MS analysis of procainamide labeled $\mathrm{N}$-glycans of ostrich egg white and yolk was carried out by a Bruker TIMS-TOF mass spectrometry (Bruker Daltonik GmbH, Bremen, Germany) combined with an Agilent 1200 series HPLC system containing 1260 series FLD detector. A tee connection was used to separate pump flow into the two equal volumes for MS and FLD detections. The mobile phases (A: $50 \mathrm{mM}$ ammonium formate $\mathrm{pH}: 4.4 ; \mathrm{B}: 100 \%$ ACN) were used for analytical separations of procainamide labeled $\mathrm{N}$-glycans. The gradient program was applied by decreasing the mobile phase B from $75 \%$ to $53 \%$ within $60 \mathrm{~min}$. Waters Glycan BEH Amide 2,5 $\mu \mathrm{m}$ (2.1 mm ID x $15 \mathrm{~cm}$ L) HILIC column was employed in the analytical separations of the $N$-glycans. The excitation and emission wavelength of the FLD detector were adjusted to $310 \mathrm{~nm}$ and $370 \mathrm{~nm}$, respectively. The flow rate was set to $0.35 \mathrm{~mL} \mathrm{~min}^{-1}$. The injection volume was $40 \mu \mathrm{L}$.

For MS parameters, the capillary voltage was adjusted to $4.5 \mathrm{kV}$. Source temperature was $250{ }^{\circ} \mathrm{C}$. Nebulizer and drying gases were set to $1.7 \mathrm{bar}$ and $6 \mathrm{~L} \mathrm{~min}^{-1}$, respectively. MS acquisition was achieved from 400 to $2500 \mathrm{~m} / \mathrm{z}$ at a frequency of $1 \mathrm{~Hz}$. The three most abundant precursors were selected at a spectra rate of $0.5 \mathrm{~Hz}$ to $2 \mathrm{~Hz}$ or MS/MS experiments.

\subsection{Data analysis}

The MS/MS spectra were first imported to Protein Scape Software (Bruker Daltonik GmbH, Bremen, Germany). GlycoQuest algorithm (search engine) was used to identify procainamide labeled $\mathrm{N}$-glycans. Carbbank was selected as a database. MS and MS/MS tolerances were adjusted to $20 \mathrm{ppm}$ and $0.05 \mathrm{Da}$. The obtained MS/MS spectra were also manually checked to determine $\mathrm{N}$-glycan structures as well as identifying $\mathrm{N}$-glycan types. The relative abundances of the detected FLD peaks were calculated by performing a total area normalization approach. To achieve this, the relative abundance of a glycan peak was found as follows:

Relative Abundance $\%=$ area of an $N$-glycan peak / the summed areas of $N$-glycan peaks $* 100$

Statistical tests were performed using Graphpad Prism 9 software. Multiple t-tests was applied to compare $\mathrm{N}$-glycan trait abundances between the ostrich egg white and yolk glycoproteomes. A probability value $(\mathrm{p}<0.01)$ was considered statistically significant.

\section{Results and Discussion}

\section{1. $N$-glycan profiling of ostrich egg white}

$\mathrm{N}$-glycans were released from ostrich egg white and labeled with procainamide. After purifications of procainamide labeled $N$-glycans, analyses were achieved by HPLC-HILIC-FLD- 
MS/MS system. MS detection was used for the identification of procainamide labeled $\mathrm{N}$-glycan structures, whereas FLD detection was performed for the relative quantification of procainamide labeled $N$-glycans. The FLD and BPC (base peak chromatogram) chromatograms of ostrich egg yolk were shown in Fig. 1. Thirty-one peaks were detected in the FLD and BPC chromatograms. When the MS/MS data searched against a Carbbank database using the glycoQuest algorithm, thirty-nine different $\mathrm{N}$-glycan structures were determined under these peaks. High-mannose, complex, hybrid, and bisected $N$-glycan types were detected. A list obtained from Proteinscape Software were displayed in Table 1.

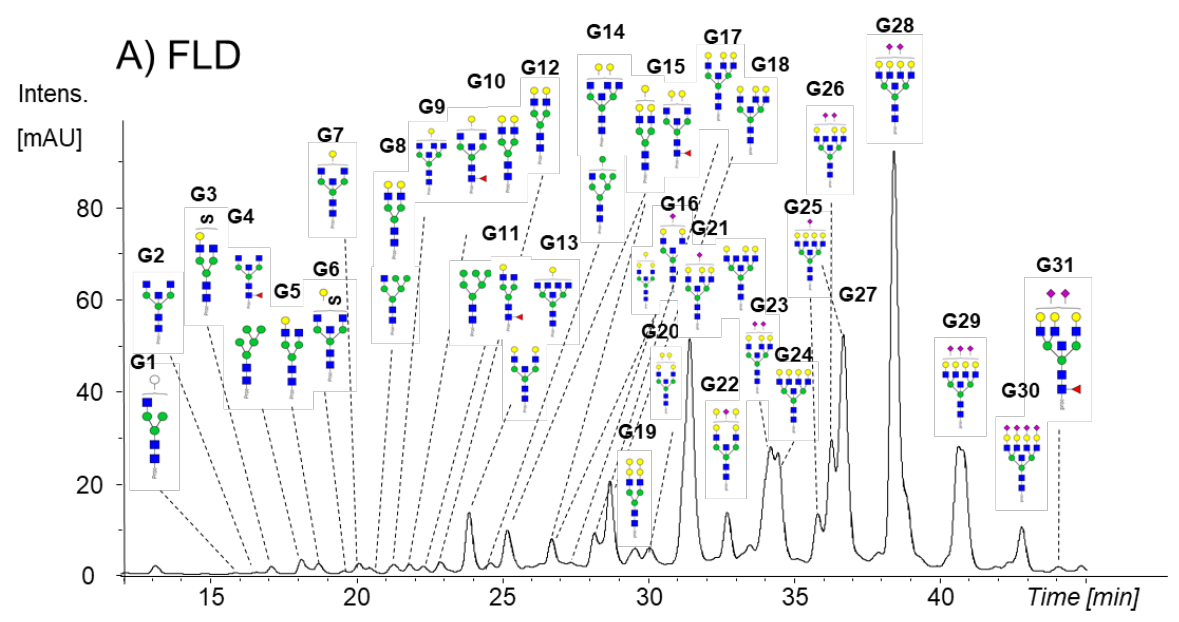

B) BPC

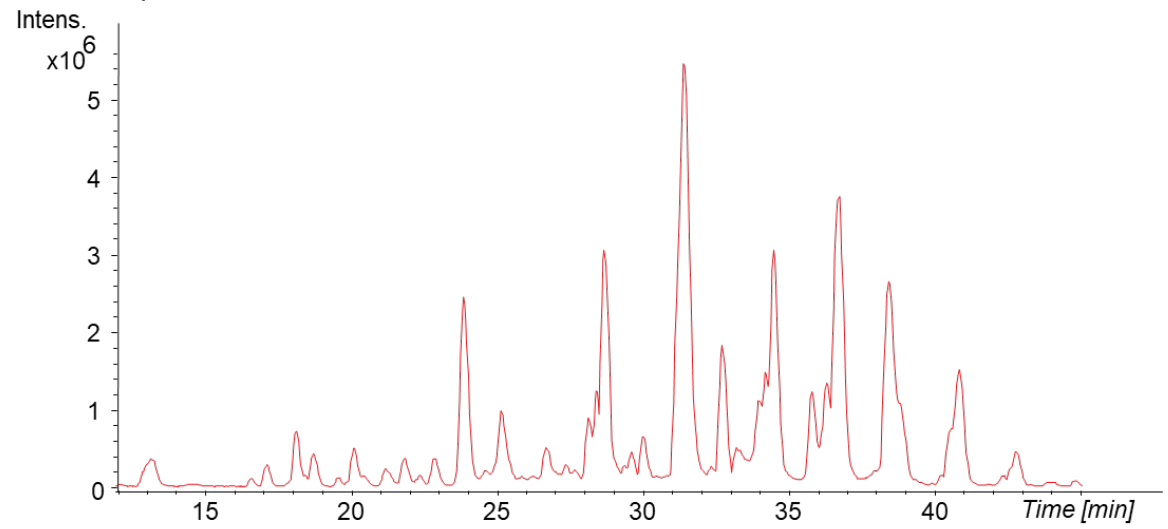

Figure 1: Fluorescence (A) and base peak chromatograms (B) of procainamide labeled $N$-glycans released from glycoproteins extracted from ostrich egg white

As shown in Fig. 1, di-, tri-, and tetra-antennary glycan types $N$-glycan structures were determined. On the other hand, most of the detected $\mathrm{N}$-glycans did not include sialic acid residues; however, sialic acid-containing $N$-glycans were the most abundant types in the related chromatogram. Sulfated $N$-glycan types with minor amounts were also detected by the analysis of the samples using HPLC-HILIC-FLD-MS/MS. It was determined that all the fucosylated glycans were core-fucosylated by following the MS/MS fragments highlighted previously in the 
literature [18]. Besides, bisected $N$-glycans were confirmed by checking the specific fragments described in the literature for bisecting $N$-glycans [17].

Table 1: The list of procainamide labeled $N$-glycans belonging to ostrich egg white glycoproteome. nd: non-detected by glycoQuest and manually identified

\begin{tabular}{|c|c|c|c|c|c|c|c|c|c|}
\hline Peak & $N$-glycan Composition & $\begin{array}{l}\mathrm{m} / \mathrm{z} \\
\text { meas. }\end{array}$ & $\mathbf{z}$ & $\begin{array}{l}\mathrm{m} / \mathbf{z} \\
\text { calc. }\end{array}$ & $\begin{array}{l}\Delta \mathrm{m} / \mathrm{z} \\
\mathbf{D a}\end{array}$ & $\begin{array}{l}\Delta \mathrm{m} / \mathrm{z} \\
\mathrm{ppm}\end{array}$ & $\begin{array}{l}\text { Rt } \\
\text { min }\end{array}$ & Scor. & $\begin{array}{r}\text { Frg. } \\
\text { Cv. } \\
\% \\
\end{array}$ \\
\hline G1 & Hex4HexNAc3 & 748.3294 & 2 & 748.3240 & 0.0053 & 7.10 & 16.05 & 75.5 & 58 \\
\hline $\mathrm{G} 2$ & Hex3HexNAc5 & 870.3830 & 2 & 870.3770 & 0.0060 & 6.88 & 16.63 & 119.7 & 172 \\
\hline G3 & Hex4HexNAc4S1 & 889.8476 & 2 & 889.8421 & 0.0054 & 6.09 & 17.06 & 79.9 & 73 \\
\hline G4 & Hex5HexNAc2 & 727.8140 & 2 & 727.8108 & 0.0033 & 4.47 & 18.06 & 96.9 & 105 \\
\hline G4 & Hex3HexNAc5dHex 1 & 943.4092 & 2 & 943.4060 & 0.0032 & 3.41 & 18.31 & 90.4 & 90 \\
\hline G5 & Hex4HexNAc4 & 849.8676 & 2 & 849.8637 & 0.0038 & 4.52 & 18.65 & 105.0 & 118 \\
\hline G6 & Hex4HexNAc5S1 & 661.2605 & 3 & 661.2570 & 0.0036 & 5.40 & 19.57 & 81.6 & 70 \\
\hline G7 & Hex4HexNAc5 & 951.4090 & 2 & 951.4034 & 0.0056 & 5.89 & 20.14 & 128.4 & 175 \\
\hline G8 & Hex 5HexNAc3 & 829.3548 & 2 & 829.3505 & 0.0043 & 5.22 & 20.39 & 92.5 & 98 \\
\hline G8 & Hex5HexNAc4 & 620.9326 & 3 & 620.9292 & 0.0034 & 5.49 & 20.43 & 50.6 & 32 \\
\hline G8 & Hex4HexNAc5 & 951.4070 & 2 & 951.4034 & 0.0036 & 3.79 & 20.65 & 94.0 & 113 \\
\hline G9 & Hex4HexNAc6 & 1052.9466 & 2 & 1052.9431 & 0.0035 & 3.32 & 21.41 & 118.3 & 185 \\
\hline G9 & Hex5HexNAc4 & 930.8946 & 2 & 930.8901 & 0.0044 & 4.76 & 21.59 & 84.9 & 80 \\
\hline G9 & Hex4HexNAc5dHex 1 & 1024.4372 & 2 & 1024.4324 & 0.0048 & 4.67 & 21.64 & 52.0 & 30 \\
\hline G10 & Hex5HexNAc4 & 930.8950 & 2 & 930.8901 & 0.0048 & 5.18 & 21.73 & 113.3 & 148 \\
\hline G10 & Hex4HexNAc5dHex 1 & 1024.4378 & 2 & 1024.4324 & 0.0054 & 5.30 & 21.74 & 84.7 & 84 \\
\hline G11 & Hex4HexNAc4dHex 1 & 922.8974 & 2 & 922.8927 & 0.0047 & 5.10 & 22.23 & 68.8 & 79 \\
\hline G11 & Hex6HexNAc2 & 808.8415 & 2 & 808.8372 & 0.0043 & 5.31 & 22.32 & 101.5 & 135 \\
\hline G13 & Hex 5HexNAc5 & 688.6270 & 3 & 688.6223 & 0.0047 & 6.87 & 23.72 & 146.6 & 230 \\
\hline G13 & Hex4HexNAc7 & 769.9960 & 3 & 769.9909 & 0.0050 & 6.50 & 24.28 & 82.9 & 78 \\
\hline G14 & Hex5HexNAc3NeuAc1 & 650.2719 & 3 & 650.2679 & 0.0041 & 6.24 & 24.34 & 60.4 & 43 \\
\hline G14 & Hex6HexNAc3 & 910.3818 & 2 & 910.3769 & 0.0049 & 5.42 & 24.57 & 101.9 & 116 \\
\hline G14 & Hex5HexNAc6 & 756.3206 & 3 & 756.3154 & 0.0051 & 6.79 & 24.86 & 125.7 & 186 \\
\hline G15 & Hex5HexNAc6 & 1133.9764 & 2 & 1133.9695 & 0.0069 & 6.10 & 24.88 & 122.2 & 183 \\
\hline G15 & Hex6HexNAc4 & 1011.9211 & 2 & 1011.9165 & 0.0045 & 4.47 & 24.97 & 107.0 & 127 \\
\hline G15 & Hex5HexNAc5dHex 1 & 737.3129 & 3 & 737.3083 & 0.0046 & 6.22 & 25.39 & 93.2 & 99 \\
\hline G16 & Hex5HexNAc5NeuAc1 & 785.6599 & 3 & 785.6541 & 0.0058 & 7.42 & 26.55 & 88.2 & 92 \\
\hline G16 & Hex6HexNAc5 & 742.6459 & 3 & 742.6399 & 0.0060 & 8.05 & 26.64 & 115.0 & 169 \\
\hline G17 & Hex6HexNAc6 & 810.3392 & 3 & 810.3330 & 0.0062 & 7.65 & 28.13 & 151.5 & 255 \\
\hline G18 & Hex6HexNAc6 & 810.3393 & 3 & 810.3330 & 0.0062 & 7.68 & 28.59 & 175.8 & 362 \\
\hline G19 & Hex7HexNAc4 & 728.9705 & 3 & 728.9644 & 0.0061 & 8.31 & 29.27 & 110.5 & 158 \\
\hline G20 & Hex6HexNAc5NeuAc1 & 1259.0120 & 2 & 1259.0039 & 0.0081 & 6.42 & 29.85 & 54.9 & 42 \\
\hline $\mathrm{G} 20$ & Hex7HexNAc5 & 796.6634 & 3 & 796.6575 & 0.0059 & 7.38 & 29.88 & 123.2 & 196 \\
\hline G20 & Hex5HexNAc5NeuAc2 & 882.6925 & 3 & 882.6859 & 0.0066 & 7.47 & 30.07 & 65.2 & 68 \\
\hline $\mathrm{G} 21$ & Hex6HexNAc6NeuAc1 & 907.3726 & 3 & 907.3648 & 0.0078 & 8.60 & 31.00 & nd & nd \\
\hline $\mathrm{G} 21$ & Hex6HexNAc7 & 878.0341 & 3 & 878.0262 & 0.0079 & 8.98 & 31.68 & 140.7 & 216 \\
\hline $\mathrm{G} 22$ & Hex7HexNAc5NeuAc1 & 893.6965 & 3 & 893.6893 & 0.0072 & 8.06 & 32.50 & nd & nd \\
\hline G23 & Hex6HexNAc6NeuAc2 & 1004.4034 & 3 & 1004.3967 & 0.0067 & 6.70 & 33.71 & 59.0 & 62 \\
\hline G24 & Hex7HexNAc7 & 932.0509 & 3 & 932.0438 & 0.0072 & 7.69 & 33.93 & 103.4 & 190 \\
\hline $\mathrm{G} 25$ & Hex7HexNAc7NeuAc1 & 1029.0827 & 3 & 1029.0756 & 0.0071 & 6.90 & 35.80 & nd & nd \\
\hline
\end{tabular}




\begin{tabular}{llllllllll}
\hline G26 & Hex6HexNAc7NeuAc2 & 1072.0964 & 3 & 1072.0898 & 0.0066 & 6.16 & 36.20 & nd & nd \\
G27 & Hex7HexNAc7NeuAc1 & 1029.0819 & 3 & 1029.0756 & 0.0063 & 6.12 & 36.70 & nd & nd \\
G28 & Hex7HexNAc7NeuAc2 & 1126.1152 & 3 & 1126.1074 & 0.0078 & 6.93 & 38.30 & nd & nd \\
G29 & Hex7HexNAc7NeuAc3 & 1223.1470 & 3 & 1223.1392 & 0.0078 & 6.38 & 40.50 & nd & nd \\
G30 & Hex7HexNAc7NeuAc4 & 1320.1823 & 3 & 1320.1710 & 0.0113 & 8.56 & 42.70 & nd & nd \\
& Hex6HexNAc6NeuAc2dHex & & & & - & & & & \\
G31 & 1 & 1579.6002 & 2 & 1579.6246 & 0.0244 & -15.4 & 44.00 & nd & nd \\
\hline
\end{tabular}

Relative abundances of the detected $\mathrm{N}$-glycans were calculated by applying the total area normalization approach. The relative abundances of the $\mathrm{N}$-glycan peaks for ostrich egg white glycoproteome were shown in Fig. 2. The analysis was achieved with three experimental replicates. The $\mathrm{N}$-glycan peak G21 (Hex6HexNAc6NeuAc1, Hex7HexNAc7NeuAc2) was found to be most abundant among $\mathrm{N}$-glycan peaks (19.23\%). The second most intense $\mathrm{N}$-glycan peak was G28 (Hex7HexNAc7NeuAc2, 17.74\%). $N$-glycan traits were derived depending on glycan types of the detected $\mathrm{N}$-glycans. It was seen that tri- and tetra-antennary type $\mathrm{N}$-glycans were the most abundant types compared to mono- and di-antennary $\mathrm{N}$-glycan types. The fucosylation ratio was found to be $4.52 \%$, whereas relative abundances of bisected $N$-glycans was $91.72 \%$ for ostrich egg white glycoproteome. In addition, the relative abundance of sialylation was found to be $61.70 \%$. High-mannose type was covered to $2.66 \%$ within the detected $N$-glycan types of ostrich egg white.

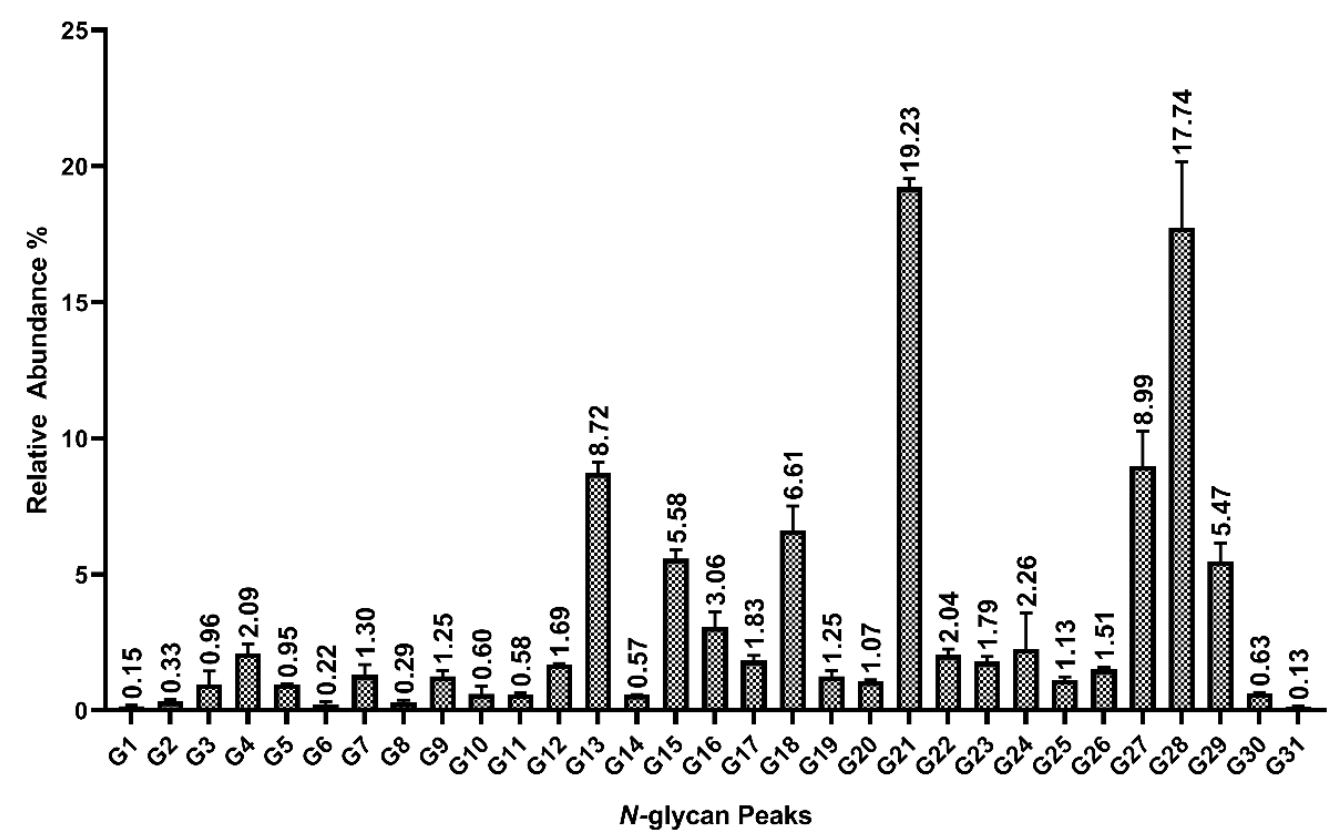

Figure 2: Relative abundances of $N$-glycan Peaks belonging to ostrich egg white glycoproteome

\section{2. $\mathrm{N}$-glycan profiling of ostrich egg yolk}


$\mathrm{N}$-glycans were released from the ostrich egg yolk glycoproteome and labeled with a procainamide tag. The labeled $N$-glycans were then analyzed by HPLC-HILIC-FLD-MS/MS system. The MS and FLD chromatograms of $N$-glycans belonging to ostrich egg yolk glycoproteome were shown in Fig. 3.

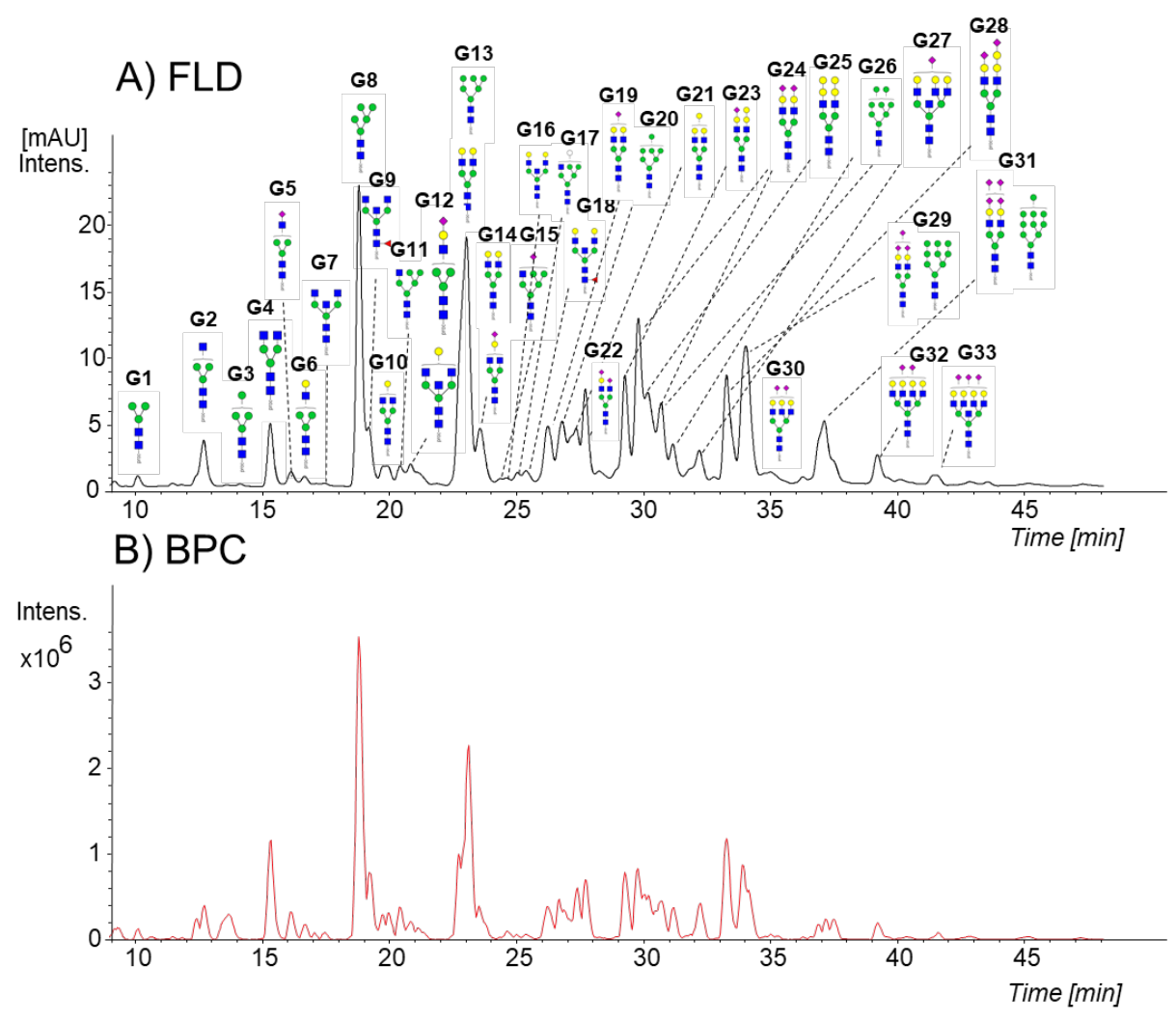

Figure 3: Fluorescence (A) and base peak chromatograms (B) of procainamide labeled $\mathrm{N}$-glycans released from glycoproteins extracted from ostrich egg yolk

Thirty-six different $N$-glycan structures were determined by the analysis of obtained MS/MS data, which were detected under $33 \mathrm{~N}$-glycan peaks in the FLD chromatogram. Similar to ostrich egg white glycoproteome, high-mannose, complex, hybrid, and bisected $N$-glycan types were determined in the analysis. The list for the detected $\mathrm{N}$-glycans from ostrich egg yolk glycoproteome was displayed in Table 2.

Table 2: The list of procainamide labeled $N$-glycans belonging to ostrich egg yolk glycoproteome. nd: nondetected by glycoQuest and manually identified

\begin{tabular}{|c|c|c|c|c|c|c|c|c|c|}
\hline Peak & $N$-glycan Composition & m/z meas. & $\mathbf{z}$ & m/z calc. & $\begin{array}{l}\Delta \mathbf{m} / \mathbf{z} \\
\mathrm{Da}\end{array}$ & $\begin{array}{l}\Delta \mathbf{m} / \mathbf{z} \\
\mathrm{ppm}\end{array}$ & $\begin{array}{l}\text { Rt } \\
\text { min }\end{array}$ & Scor. & $\begin{array}{r}\text { Frg. } \\
\text { Cv. } \\
\%\end{array}$ \\
\hline G1 & Hex3HexNAc2 & 565.7571 & 2 & 565.7579 & -0.0009 & -1.50 & 10.22 & 82.2 & 77 \\
\hline G2 & Hex3 & 667.2967 & 2 & 667.2976 & -0.0009 & -1.33 & 12.70 & 89.3 & 89 \\
\hline G3 & Hex4HexNAc2 & 646.7828 & 2 & 646.7844 & -0.0015 & -2.38 & 14.20 & 76.8 & 69 \\
\hline G4 & Hex3HexNAc4 & 768.8367 & 2 & 768.8373 & -0.0006 & -0.78 & 15.24 & 95.5 & 104 \\
\hline
\end{tabular}




\begin{tabular}{|c|c|c|c|c|c|c|c|c|c|}
\hline G5 & ex31 & 2.8444 & 2 & 812.8453 & -0.0009 & -1.11 & 16.10 & nd & nd \\
\hline G6 & & & 2 & & & & & & 39 \\
\hline G7 & & & 2 & & & & & & 86 \\
\hline G8 & $\times 5 \mathrm{H}$ & & 2 & & .0008 & & & & 83 \\
\hline G9 & $\mathrm{x} 1$ & 38 & 2 & & 22 & 1 & 08 & 74 & 7ר \\
\hline G10 & & & 2 & & & & & 10 & 113 \\
\hline G11 & & & 2 & & & & & 10 & 17 \\
\hline G12 & 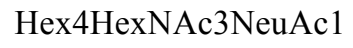 & & 2 & 893 & 12 & -1.31 & & & 57 \\
\hline G12 & $x^{4}$ & 18 & 2 & 951 & -0.0016 & -1.69 & 20.97 & 93 & 108 \\
\hline $\mathrm{G} 13$ & & & 2 & & & 4 & & 10 & 135 \\
\hline G13 & & & 2 & & & & & & 80 \\
\hline G13 & & & 2 & & & & & & 148 \\
\hline G14 & & 90 & 2 & 93( & $-0 .(1+x-1)-x$ & -1.21 & 43 & 10 & 116 \\
\hline G1 & & & 2 & & & & & & 76 \\
\hline G15 & & & 2 & & & & & & 55 \\
\hline G16 & & & 2 & & & & & & 107 \\
\hline G1 & & & 2 & & & 7 & & & 90 \\
\hline $\mathrm{G} 18$ & & & 4 & & & & & & 39 \\
\hline G19 & & & 2 & & & & & & 79 \\
\hline G20 & & & 2 & & & & & & 141 \\
\hline G2 & & & 2 & & & -2 & & & 107 \\
\hline $\mathrm{G} 22$ & & & 3 & & & -0.70 & & 97 & 101 \\
\hline G23 & 1 & & 3 & 77 & & 2 & 23 & & 77 \\
\hline G24 & & & 3 & & & & & & 98 \\
\hline G25 & & & 3 & & & & .22 & 112 & 134 \\
\hline G26 & & & 2 & & -0 & -2.10 & 0.35 & 120.1 & 155 \\
\hline G27 & & & 3 & & & & $d$ & & ad \\
\hline G28 & & .0094 & 3 & 869.0104 & -0.0010 & & 3.17 & 77.9 & 68 \\
\hline $\mathrm{G} 2 \mathrm{~S}$ & & & 3 & & -0.0020 & -2 & 46 & & 62 \\
\hline G29 & & & 2 & & & & & 74 & 81 \\
\hline G30 & & & 3 & & & & & & 64 \\
\hline G31 & & 1132.9415 & 2 & 1132.9428 & -0.0013 & -1.18 & 36.74 & 130.5 & 190 \\
\hline $\mathrm{G}$ & & & 3 & 926 & -0.0027 & -2.68 & & 77.9 & 69 \\
\hline G32 & & & 4 & & & -0.71 & & . & nd \\
\hline U5J & Hex7HexNAc7NeuAc3 & 917.6066 & 4 & 917.6062 & 0.0004 & 0.44 & 41.50 & 10 & \\
\hline
\end{tabular}

The relative abundances of the $\mathrm{N}$-glycan peaks for ostrich egg white glycoproteome were shown in Fig. 2. The $N$-glycan peak G13 (Hex5HexNAc4, Hex4HexNAc4NeuAc1, and Hex6HexNAc2) was found to be most abundant among $N$-glycan peaks $(21.23 \%)$. The second most intense $N$-glycan peak was found to be G8 (Hex5HexNAc2, 15.42\%). $N$-glycan traits were derived depending on glycan types of the detected $N$-glycans. It was noticed that the fucosylation ratio was found to be $0.95 \%$. At the same time, relative abundances of bisected $N$-glycans was $6.74 \%$ for ostrich egg yolk glycoproteome. In addition, the relative abundance of sialylation was found to be $46.40 \%$. High-mannose type was covered to $55.84 \%$ within the detected $\mathrm{N}$-glycan types for ostrich egg yolk. 


\section{Ostrich Egg Yolk Glycoproteome}

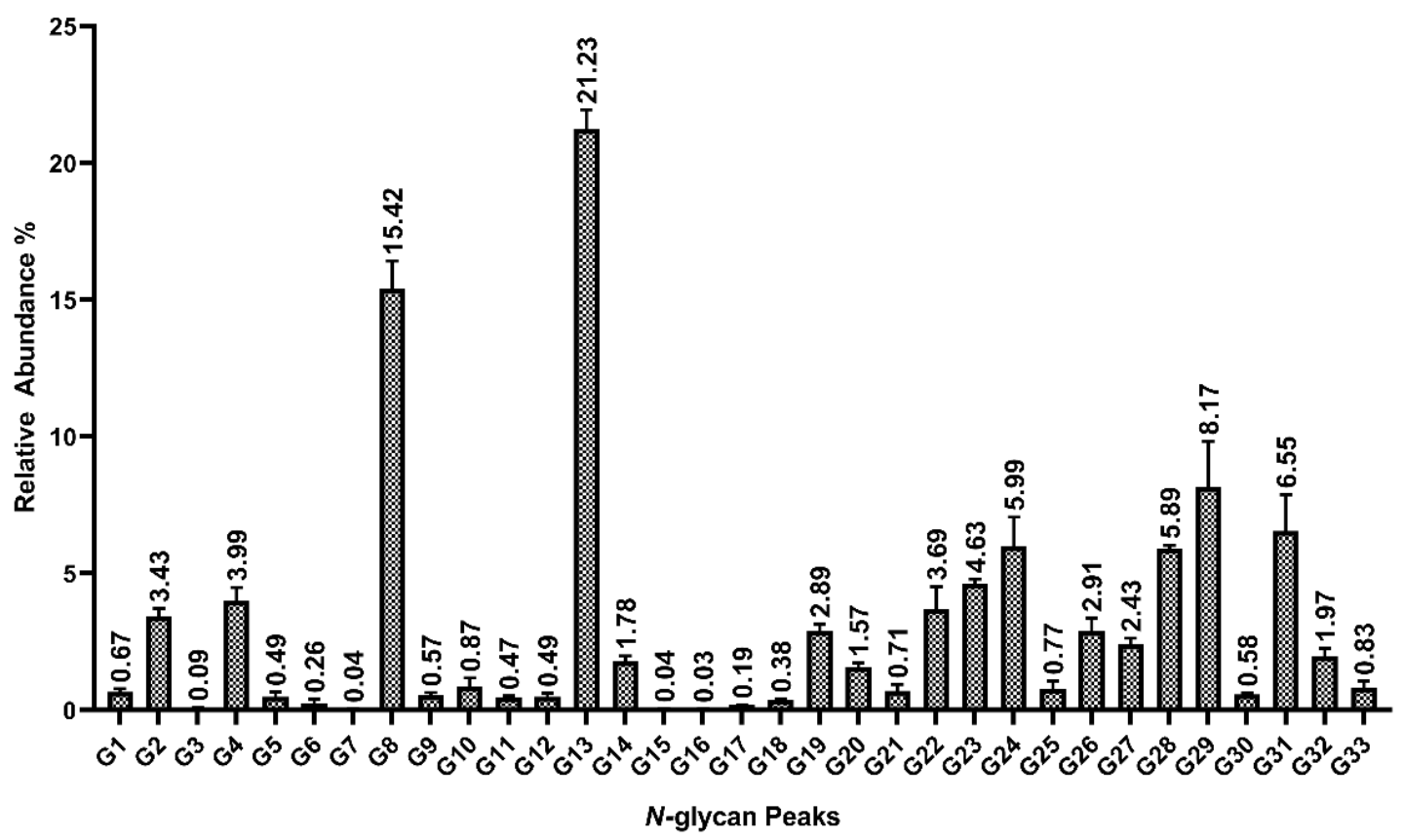

Figure 4: Relative abundances of $N$-glycan Peaks belonging to ostrich egg yolk glycoproteome

\subsection{Comparison of $N$-glycan types and traits between ostrich egg white and yolk} glycoproteome

The type of the detected $N$-glycans was compared in the study for ostrich egg white and yolk glycoproteomes. The results showed that the $18 \mathrm{~N}$-glycan structures were identified in both species. Twenty-one $N$-glycan structures were only found in the ostrich egg white glycoproteome, whereas $19 \mathrm{~N}$-glycan structures were detected in the ostrich egg yolk glycoproteome. Bisected $\mathrm{N}$ glycan types were more abundant in ostrich egg white glycoproteome than ostrich egg yolk. However, the number of high-mannose $\mathrm{N}$-glycan types detected by the analysis of ostrich egg yolk glycoproteome was higher compared with ostrich egg white glycoproteome.

The relative abundances of $\mathrm{N}$-glycan traits were derived from $\mathrm{N}$-glycans detected from the analysis using HPLC-HILIC-FLD-MS/MS for both ostrich egg white and yolk glycoproteomes. The comparisons of derived $\mathrm{N}$-glycan traits were shown in Fig. 5. The fucosylation ratio was found to be low for both glycoproteomes. The relative abundance of bisecting $\mathrm{N}$-glycans was dramatically abundant in ostrich egg white glycoproteome (91.72\%). In contrast, high-mannose $\mathrm{N}$-glycans were covered abundantly in ostrich egg yolk glycoproteome (55.84\%). The $\mathrm{N}$-glycans of ostrich egg white glycoproteome was highly galactosylated (96.64\%), while this was $72.38 \%$ 
for the $\mathrm{N}$-glycans of ostrich egg yolk glycoproteome. Sialylation of ostrich egg white glycoproteome was higher than that of ostrich egg yolk glycoproteome.

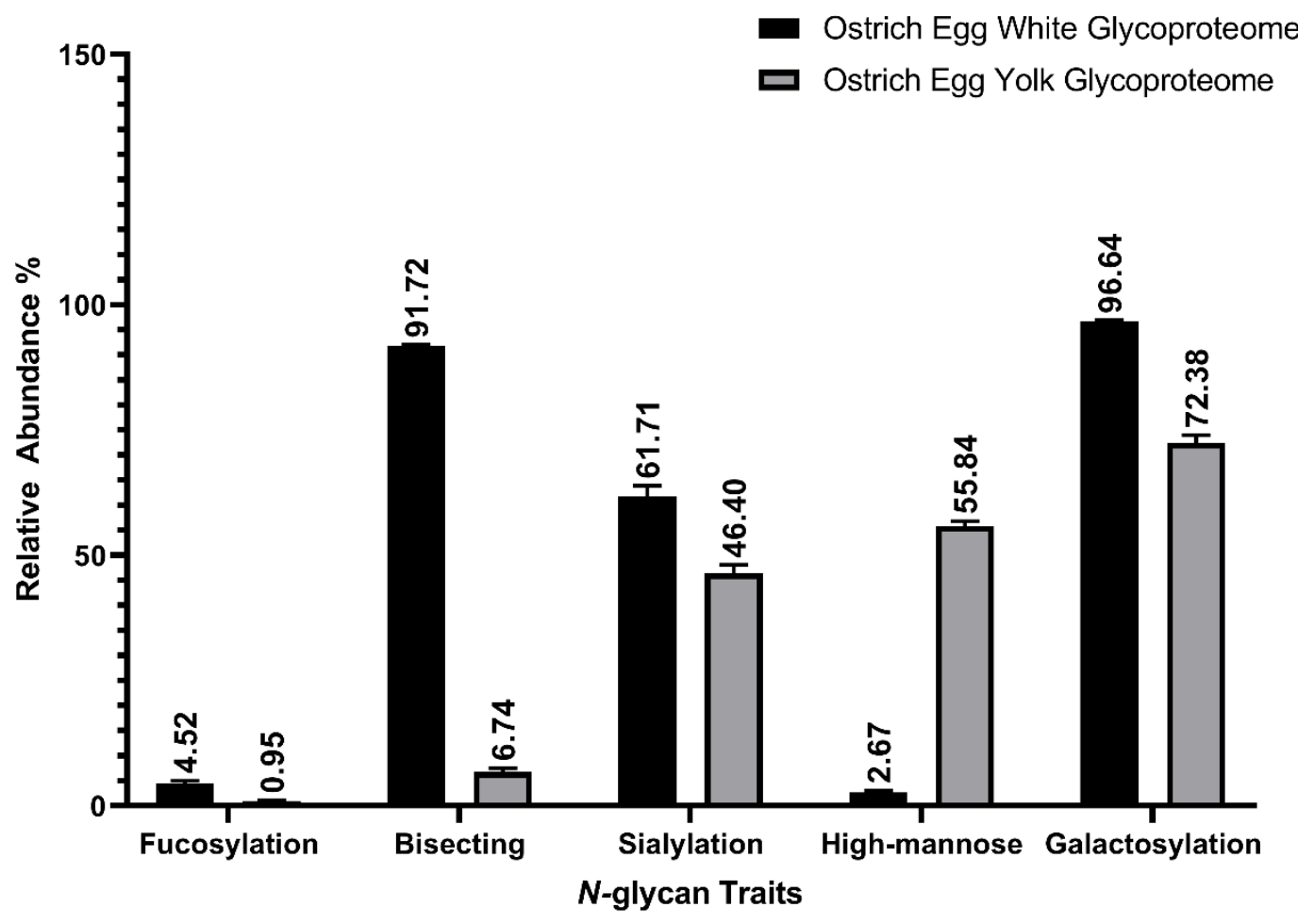

Figure 5: Relative abundances of $\mathrm{N}$-glycan traits belonging to ostrich egg white and yolk glycoproteome

Multiple t-test comparisons were also achieved to determine significant changes between both glycoproteomes. The results obtained from multiple t-test analyses were displayed in Table 3. As shown in Table 3 that all $\mathrm{N}$-glycan traits obtained from ostrich egg white and yolk glycoproteomes differed significantly at the significant level of $\mathrm{p}<0.01$.

Table 3: Multiple t-test comparison results of $N$-glycan traits.

\begin{tabular}{llllllll}
\hline & & $\begin{array}{l}\text { Mean of Ostrich } \\
\text { P-value }\end{array}$ & $\begin{array}{l}\text { Eean of } \\
\text { Glycoproteome } \\
\text { Ostrich Egg } \\
\text { Yolk } \\
\text { Glycoproteome }\end{array}$ & $\begin{array}{l}\text { Mean } \\
\text { Difference }\end{array}$ & $\begin{array}{l}\text { Standard } \\
\text { Error of } \\
\text { Difference }\end{array}$ & $\begin{array}{l}\text { t ratio } \\
\text { Fold } \\
\text { Ratio }\end{array}$ \\
\hline Fucosylation & 0.0005 & 4.52 & 0.95 & 3.57 & 0.35 & 10.17 & 4.75 \\
Bisecting & $<0.0001$ & 91.72 & 6.74 & 84.99 & 0.59 & 144.20 & 13.62 \\
Sialylation & 0.0015 & 61.70 & 46.40 & 15.30 & 1.96 & 7.80 & 1.33 \\
High-mannose & $<0.0001$ & 2.66 & 55.84 & -53.18 & 0.71 & 75.34 & 0.05 \\
Galactosylation & $<0.0001$ & 96.64 & 72.38 & 24.26 & 1.16 & 21.00 & 1.34 \\
\hline
\end{tabular}




\section{Conclusion}

In-depth $N$-glycan profiling of ostrich egg white and yolk glycoproteomes was achieved using a facile glycomics protocol. The number of detected $\mathrm{N}$-glycans belonging to ostrich egg white and yolk glycoproteomes was found to be 39 and 36, respectively. Ostrich egg white glycoproteome was highly galactosylated compared to egg yolk. In addition, the abundance of bisecting $\mathrm{N}$-glycans was dramatically high in ostrich egg white glycoproteome. However, highmannose type $\mathrm{N}$-glycans were abundant in ostrich egg yolk glycoproteome. This study will contribute to the nutritional glycomics field regarding the structural $\mathrm{N}$-glycan analysis of ostrich egg white and yolk glycoproteomes.

\section{Acknowledgments}

The author thanks Dr. Bekir Salih for his valued help to use his laboratory facilities and Dr. Sercan Karav for providing ostrich eggs.

\section{References}

[1] Başaran, E., Aras, S., Cansaran-Duman, D., Genomik, proteomik, metabolomik kavramlarına genel bakışve uygulama alanları, Türk Hijyen ve Deneysel Biyoloji Dergisi, 67, 85-96, 2010.

[2] Vu, L.D., Gevaert, K., De Smet, I., Protein language: post-translational modifications talking to each other, Trends in Plant Science, 23, 1068-1080, 2018.

[3] Oliveira-Ferrer, L., Legler, K., Milde-Langosch, K., Role of protein glycosylation in cancer metastasis, Seminars in Cancer Biology, 44, 141-152, 2017.

[4] Mathew, M.P., Donaldson, J.G., Glycosylation and glycan interactions can serve as extracellular machinery facilitating clathrin- independent endocytosis, Traffic, 20, 295-300, 2019.

[5] Özaydin, E., Yalçin, F., Gündüz, M., Köse, G., Konjenital glikozilasyon bozukluğu tip II, Türkiye Çocuk Hastalıkları Dergisi, 6, 47-53, 2012.

[6] Omana, D.A., Wang, J., Wu, J., Ovomucin - a glycoprotein with promising potential. Trends Food Sci Technol., 21, 455-463, 2010.

[7] Kobayashi, K., Hattori, M., Hara-Kudo, Y., Okubo, T., Yamamoto, S., Takita, T., Sugita-Konishi, Y., Glycopeptide derived from hen egg ovomucin has the ability to bind enterohemorrhagic Escherichia coli O157:H7, J Agric Food Chemistry, 52, 5740-5746, 2004.

[8] Sharif, M.K., Saleem, M., Javed, K., Chapter 15 - Food materials science in egg powder industry, Role of Materials Science in Food Bioengineering, Elsevier press, 505-537, 2018.

[9] Kovacs-Nolan, J., Phillips, M., Mine, Y., Advances in the value of eggs and egg components for human health, Journal of Agricultural and Food Chemistry, 53, 8421-8431, 2005. 
[10] Smith, D.F., Cummings, R.D., Song, X., History and future of shotgun glycomics, Biochemical Society Transactions, 1, 1-11, 2019.

[11] Dong, X., Huang, Y., Cho, B.G., et al., Advances in mass spectrometry- based glycomics, Electrophores1s, 39, 3063-3081, 2018.

[12] Keser, T., Pavić, T., Lauc, G., Gornik, O., Comparison of 2-Aminobenzamide, Procainamide and RapiFluor-MS as derivatizing agents for High-Throughput HILIC-UPLCFLR-MS N-Glycan analysis, Frontiers in Chemistry, 6, 324, 2018.

[13] Kayili, H.M., Avci, İ., Salih, B., A new Titania Glyco-Purification Tip for the fast enrichment and efficient analysis of glycopeptides and glycans by MALDI-TOF-MS, Journal of Pharmaceutical and Biomedical Analysis, 174, 191-197, 2019.

[14] Kayili, H.M., Barlas, N., Atakay, M., Salih, B., Fast purification of glycans and glycopeptides using silk-packed micropipette tip for matrix-assisted laser desorption/ionizationmass spectrometry and high-performance liquid chromatography-fluorescence detection analysis, Microchemical Journal, 139, 492-499, 2018.

[15] Kayili, H.M., Ertürk, A.S., Elmac1, G., Salih, B., Poly(Amidoamine) dendrimer-coated magnetic nanoparticles for the fast purification and selective enrichment of glycopeptides and glycans, Journal of Separation Science, 42, 3209-3216, 2019.

[16] Kozak, R.P., Tortosa, C.B., Fernandes, D.L., Spencer, D.I.R., Comparison of procainamide and 2-aminobenzamide labeling for profiling and identification of glycans by liquid chromatography with fluorescence detection coupled to electrospray ionization-mass spectrometry, Analytical Biochemistry, 486, 38-40, 2015.

[17] Kayili, H.M., Identification of bisecting $N$-glycans in tandem mass spectra using a procainamide labeling approach for in-depth $N$-glycan profiling of biological samples, International Journal of Mass Spectrometry, 457, 116412, 2020.

[18] Nwosu, C., Yau, H.K., Becht, S., Assignment of core versus Antenna Fucosylation types in protein $N$-Glycosylation via procainamide labeling and tandem mass spectrometry, Analytical Chemistry, 87, 5905-5913, 2015. 